\title{
Comment
}

\section{Merging self-driving cars with the Law}

\author{
Jan De Bruyne*, Jarich Werbrouck \\ Department of Interdisciplinary Study of Law, Private Law and Business Law, University of \\ Ghent, Belgium
}

\begin{abstract}
Self-driving cars are gradually being introduced in the United States and in several Member States of the European Union. Policymakers will thus have to make important choices regarding the application of the law. One important aspect relates to the question who should be held liable for the damage caused by such vehicles. Arguably, product liability schemes will gain importance considering that the driver's fault as a cause of damage will become less likely with the increase of autonomous systems. The application of existing product liability legislation, however, is not always straightforward. Without a proper and effective liability framework, other legal or policy initiatives concerning technical and safety matters related to self-driving cars might be in vain. The article illustrates this conclusion by analysing the limitation periods for filing a claim included in the European Union Product Liability Directive, which are inherently incompatible with the concept of autonomous vehicles. On a micro-level, we argue that every aspect of the Directive should be carefully considered in the light of the autonomisation of our society. On the macro-level, we believe that ongoing technological evolutions might be the perfect moment to bring the European Union closer to its citizens.
\end{abstract}

(C) 2018 Jan De Bruyne \& Jarich Werbrouck. Published by Elsevier Ltd. All rights reserved.

Keywords: Self-Driving Cars - Product Liability Directive - Technological Evolutions - Legal Issues

\section{Legal Framework on Self-Driving Cars in the European Union and the United States}

Self-driving or autonomous cars are no longer a futuristic fantasy or part of a science-fiction movie. According to recent predictions, fully autonomous or driverless vehicles might be available within five years. ${ }^{1}$ Today, companies such as Google and Samsung are already testing prototypes of such vehicles on public roads. The introduction of autonomous cars will have an enormous impact on different aspects of society and on our current way of living and thinking. Policymakers will have to make

\footnotetext{
* Corresponding author: Jan De Bruyne, Center of Contract Law, Department of Interdisciplinary Study of Law, Private Law and Business Law, Faculty of Law and Criminology, University of Ghent, Universiteitstraat 4, 9000 Ghent, Belgium.

Email address: jandbruy.debruyne@ugent.be Tel: +32(4)74933677.

.${ }^{1}$ James M. Anderson, Nidhi Kalra, Karlyn D. Stanley, Paul Sorensen, Constantine Samaras \& Oluwatobi A. Oluwatola, Autonomous Vehicle Technology - A Guide for Policymakers (RAND Corporation, 2016, 4) <https://www.rand.org/pubs/research_reports/RR443-2.html> accessed 24 January 2018; Gillian Yeomans, Autonomous Vehicles - Handing over control: opportunities and risks for insurance (Lloyd's, 2014, 9) <https://www.lloyds.com/news-and-insight/risk-insight/library/technology/autonomous-vehicles> accessed 24 January 2018.
} 
choices with regard to certain aspects related to such vehicles. ${ }^{2}$ It is, therefore, no surprise that legislation covering the testing, production and marketing of autonomous cars is gradually being implemented at both sides of the Atlantic.

In the United States, for instance, the House of Representatives passed the Safely Ensuring Lives Future Deployment and Research in Vehicle Evolution Act or the 'SELF DRIVE' Act in September 2017. The Act aims to ensure the safety of highly automated vehicles by encouraging their testing and deployment. The SELF DRIVE Act gives the National Highway Traffic Safety Administration the power to regulate the design, construction or performance of autonomous vehicles, automated driving systems or components thereof. The Act also requires manufacturers to establish cybersecurity plans as well as a privacy plan, which has to describe how the information of vehicle owners or its occupants is collected, used, shared and stored. Moreover, the SELF DRIVE Act allows manufacturers to obtain safety exemptions to use up to 25,000 autonomous vehicles without complying with existing safety standards (the Federal Motor Vehicle Safety Standards) in the first year. This cap can rise up to 100,000 vehicles annually over three years. This exemption, however, can only be obtained if manufacturers can demonstrate that their vehicles provide an overall safety level, which is at least equal to the overall safety level of non-exempted vehicles. ${ }^{3}$

At the European Union level, the GEAR 2030 High Level Group addressed several aspects related to automated and connected vehicles as well. In its Final Report, the Group concluded that large-scale tests are necessary to make progress with regard to technological aspects for those vehicles expected beyond 2020. Such tests are also important to develop relevant rules, increase public acceptance and enhance co-operation between the involved actors. The High Level Group acknowledged that many activities on autonomous vehicles are already taking place in different Member States and within the European Commission. Several Member States have a national strategy for automated and connected driving or allow large-scale tests with autonomous vehicles. ${ }^{4}$ In Belgium, for instance, the Flemish Government recently decided to invest $€ 3$ million in a test project for self-driving cars. By 2019, such vehicles should be driving around on the Belgian public roads. To that end, the road infrastructure will soon be adapted on certain parts of the highway. ${ }^{5}$

\section{Technical and Safety Legislation and an Adequate Liability Framework}

Such actions allow and even encourage manufacturers to test autonomous vehicles with the aim of improving their overall functioning and increasing the safety level. However, several legal challenges

\footnotetext{
${ }^{2}$ See in this regard: International Transport Forum, Automated and autonomous driving - Regulation under uncertainty (OECD, 2015) <http://www.oecd-ilibrary.org/transport/automated-and-autonomousdriving_5jlwvzdfk640-en> accessed 24 January 2018; Daniel J. Fagnant \& Kara Kochelman, "Preparing a nation for autonomous vehicles: opportunities, barriers and policy recommendations" (2015) 77 Transportation Research Part A: Policy and Practice 167; Harry Surden \& Mary-Anne Williams, "Technological Opacity, Predictability, and Self-Driving Cars" (2016) 38 Cardozo Law Review 121, Brian A. Browne, "Self-Driving Cars: On the Road to a New Regulatory Era" (2017) 8 Case Western Reserve Journal of Law, Technology and the Internet 1; Jessica S. Brodsky, "Autonomous Vehicle Regulation: How an Uncertain Legal Landscape May Hit the Brakes on Self-Driving Cars" (2016) 31 Berkeley Technology Law Journal 851.

${ }^{3}$ Safely Ensuring Lives Future Deployment and Research in Vehicle Evolution Act (2017) <https://congress.gov/bill/115th-congress/house-bill/3388/text> accessed 24 January 2018. See in this regard also: Daniel A. Crane, Kyle D. Logue \& Bryce C. Pilz, "A Survey of Legal Issues Arising from the Deployment of Autonomous and Connected Vehicles" (2017) 23 Michigan Telecommunications and Technology Law Review 191.

${ }^{4}$ High Level Group on the Competitiveness and Sustainable Growth of the Automotive Industry in the European Union (GEAR 2030), Ensuring that Europe has the most competitive, innovative and sustainable automotive industry of the 2030s and beyond (2017, EU, 40-48) <https://ec.europa.eu/docsroom/documents/26081> accessed 24 January 2018.

${ }^{5}$ Kristof Van der Stadt, "Vlaanderen investeert in supercomputer, zelfrijdende auto's en onderwaterrobots", Knack Datanews, 26 December 2017 <http://datanews.knack.be/ict/nieuws/vlaanderen-investeert-insupercomputer-zelfrijdende-auto-s-en-onderwaterrobots/article-normal-943671.html> accessed 24 January 2018.
} 
remain. ${ }^{6}$ Those will need to be overcome before society can fully enjoy all the benefits of automated traffic. One of the major challenges relates to the question who should be held liable for the damage caused by autonomous vehicles. The answer to this question has a wider impact on the commercialisation and use of self-driving cars and is, therefore, of particular importance. ${ }^{7}$ As rightly concluded by Schellekens in a previous interesting and innovative contribution in this journal, '[1]iability and innovation are not isolated from each other but influence each other' ${ }^{8}$ The author continues and warns for the 'chilling effect of liability law' leading to 'a delay in the introduction of automated cars'. ${ }^{9}$ Whereas specific legislation is thus adopted to increase the safety and working of autonomous vehicles, the existing legislation on liability might be essential to determine whether producers will introduce autonomous vehicles and how fast this will happen. Much of the (technical) legislation or testing programs and initiatives might somewhat be in vain if the legal framework on liability is not adapted accordingly. ${ }^{10}$

As it remains uncertain whether autonomous vehicles will still have a 'driver' who can be held liable, the manufacturers of the software or the vehicle are interesting parties to target as 'deep-pocket' defendants. ${ }^{11}$ Legislation dealing with their liability will, therefore, become important in the near future. In that regard, the GEAR 2030 High Level Group concluded that the motor insurance and product liability directives are sufficient at least for those systems expected by 2020. After that date, however, the application of the EU Directive on Product Liability risks to create a number of problems. ${ }^{12}$ According to the Directive, the producer will be held liable for damage caused by a defect in his product (so-called strict liability). ${ }^{13}$ The Product Liability Directive dates from 1985, a period in which software was not as widely used and important as it is nowadays. Some of the concepts it uses should thus be thoroughly and carefully assessed and reconsidered. This will subsequently allow policymakers to adapt the applicable legal framework in the light of the robotisation and autonomisation of our society.

\footnotetext{
${ }^{6}$ See for a discussion of some of these challenges: Nick Belay, "Robot Ethics and Self-Driving Cars: How Ethical Determinations in Software Will Require a New legal Framework", (2015) 40 Journal of the Legal Profession, 119; Peter J. Pizzi, "Connected Cars and Automated Driving: Privacy Challenges on Wheels", (2017) 84 Defense Counsel Journal 1; Francesca Favarò, Sky Eurich \& Nazanin Nader, “Autonomous vehicles' disengagements: Trends, triggers and regulatory limitations" (2018) 110 Accident Analysis \& Prevention 136; Cesare Bartolini, Tamás Tettamanti \& István Varga, "Critical features of autonomous road transport from the perspective of technological regulation and law" (2017) 27 Transportation Research Procedia 790; Daniel J. Fagnant \& Kara Kochelman, "Preparing a nation for autonomous vehicles: opportunities, barriers and policy recommendations" (2015) 77 Transportation Research Part A: Policy and Practice 167.

${ }^{7}$ Jan De Bruyne \& Jochen Tanghe, "Liability for Damage Caused by Autonomous Vehicles: a Belgian Perspective" (2017) 8 Journal of European Tort Law 324; Andrzej Rapaczynski, "Driverless Cars and the Much Delayed Tort Law Revolution" (2016) Columbia Law and Economics Working Paper No. 540 <https://papers.ssrn.com/sol3/papers.cfm?abstract_id=2764686> accessed 24 January 2018. ${ }^{8}$ Maurice Schellekens, "Self-driving cars and the chilling effect of liability law" (2015) 31 Computer Law \& Security Review 510.

${ }^{9}$ Ibid 511.

${ }^{10}$ Ibid 511-512; Andrzej Rapaczynski, “Driverless Cars and the Much Delayed Tort Law Revolution” (2016) Columbia Law and Economics Working Paper No. 5403.

${ }^{11}$ Jan De Bruyne \& Jochen Tanghe, "Liability for Damage Caused by Autonomous Vehicles: a Belgian Perspective" (2017) 8 Journal of European Tort Law 334-348 and 364-370 with further references; Nidhi Kalra, James M. Anderson \& M. Wachs, Liability and Regulation of Autonomous Vehicle Technologies (2009, RAND Corporation, 24)

<https://www.researchgate.net/publication/228931139_Liability_and_Regulation_of_Autonomous_Vehicle_Tec hnologies> accessed 24 January 2018.

${ }^{12}$ High Level Group on the Competitiveness and Sustainable Growth of the Automotive Industry in the European Union (GEAR 2030), Ensuring that Europe has the most competitive, innovative and sustainable automotive industry of the 2030s and beyond (2017, EU, 43-44).

${ }^{13}$ Council Directive 85/374/EEC of 25 July 1985 on the approximation of the laws, regulations and administrative provisions of the Member States concerning liability for defective products [1985] OJ L/210.
} 


\section{Legal Issues and Technological Challenges - The Need for an 'Overall Approach'}

Some of these elements have already been addressed extensively in different studies. Attention has, for instance, been given to the question whether software can be qualified as a product falling within the scope of the Directive ${ }^{14}$ as well as to the consequences of the broad definition of 'defect' ${ }^{15}$ (i.e. the consumer-expectation test). ${ }^{16}$ Yet, the Product Liability Directive risks becoming problematic in the digital age for other reasons as well. Discussions should not be restricted to these two issues but also focus on other elements. An 'overall approach' at the supranational level involving experts from different fields is necessary to adequately respond to the challenges associated with technological evolutions. This 'overall approach' is required as specific remedies and answers to legal issues will often entail technical elements as well. As illustration, we will focus on an important legal aspect of the Product Liability Directive that might collide with autonomous systems, namely the time limitations and expiry periods to file a claim against the producer.

The Product Liability Directive contains a limitation period under which claims can be filed against the manufacturer of the product. A period of three years applies to proceedings for the recovery of damages. The limitation period runs from the day on which the plaintiff became aware or should reasonably have become aware of the damage, the defect and the identity of the producer. Moreover, the plaintiff's right to make a claim based on the Directive is extinguished upon the expiry of ten years from the date on which the producer put the product into circulation. Especially this last requirement can be problematic in the context of autonomous vehicles. ${ }^{17}$

Problems can exist because the software incorporated in the vehicle is regularly updated. The question, for instance, arises whether a software update implies that the autonomous vehicle as a whole can be considered a new product, regardless of the actual qualification of software. The European Commission stresses in its Notice 2016/C 272/01 that a product, which has been subject to important changes or overhauls aiming to modify its original performance, purpose or type may be considered as a new product. ${ }^{18}$ Products that have been repaired or exchanged, without changing the original performance, purpose or type cannot be considered as new products. ${ }^{19}$ In the same Notice, the Commission stipulates that software updates or repairs could be assimilated to maintenance operations if they do not modify a product already placed on the market in such a way that compliance with the applicable requirements may be affected. ${ }^{20}$ Thus, a software update will not lead to a new product put into circulation if the updated vehicle is not modified in a way making it necessary to undergo a full conformity assessment again. This conformity assessment serves to assess whether or not the new risk

\footnotetext{
${ }^{14}$ Article 2 of the Product Liability Directive defines product as "all movables, with the exception of primary agricultural products and game, even though incorporated into another movable or into an immovable".

${ }^{15}$ Article 6 of the Product Liability Directive stipulates that a product is defective when "it does not provide the safety which a person is entitled to expect, taking all circumstances into account".

${ }^{16}$ See in this regard: Jan De Bruyne \& Jochen Tanghe, "Liability for Damage Caused by Autonomous Vehicles: a Belgian Perspective" (2017) 8 Journal of European Tort Law 355-362 with further references (concluding that software falls within the scope of the Directive and warning that the benchmark of legitimate expectations under the current consumer-expectation test almost meets absolute safety). See in general on liability issues related to self-driving cars: Sabine Gless, Emily Silverman, Thomas Weigend, "If Robots Cause Harm, Who Is to Blame: Self-Driving Cars and Criminal Liability" (2016) 19 New Criminal Law Review 412; Melinda Florina Lohmann, "Liability Issues concerning Self-Driving Vehicles" (2016) 7 European Journal of Risk Regulation 335; Jeffrey R. Zohn, "When Robots Attack: How Should the Law Handle Self-Driving Cars That Cause Damages" (2015) 2 University of Illinois Journal of Law, Technology \& Policy 461; Kyle Colonna, "Autonomous Cars and Tort Liability" (2012) 4 Case Western Reserve Journal of Law, Technology and the Internet 81; Bryant Walker Smith, "Automated Driving and Product Liability", (2017) 1 Michigan State Law Review 1.

${ }^{17}$ Article $10 \& 11$ of the Product Liability Directive.

${ }^{18}$ Commission, 'The 'Blue Guide' on the implementation of EU products rules 2016' (Notice) COM (2016) 272/01 15 .

${ }^{19}$ Ibid 17

${ }^{20}$ Ibid.
} 
profile of the product endangers the health and safety of persons and animals, as well as the protection of properties. ${ }^{21}$ Whether an autonomous vehicle should be considered as new after a software update will be determined by the question to what extent the update changed the 'traffic behaviour' of the vehicle. Two scenarios with different implications can arise in this regard.

Assuming, on the one hand, that the self-driving car will indeed be considered as a new product after a software update, a new expiry term of ten years will start from the moment the autonomous vehicle is put into circulation again, namely after the moment when the software is installed. This new expiry term also applies to parts of the vehicle that were already put into circulation before the software update but that are 're-put' into circulation as part of the new vehicle as a whole. Imagine the following situation. I buy an autonomous vehicle in 2018. The brakes are part of the vehicle and are thus already put into circulation by that moment. In 2027, the software is updated and a new ten yearsexpiry term arises for the updated autonomous vehicle. In 2036, damage is caused by a defect in the brakes, which have not been changed since 2018 . Therefore, the producer actually compensates the damage caused by defective brakes eighteen years after they were initially put into circulation, without having been changed or modified since then, because the vehicle is considered a new product put into circulation after the software update. This undermines the effectiveness of the ten years-expiry term as the producer can still be held liable for a defect in his product that has been existing for more than ten years.

On the other hand, one can depart from the assumption that the updated autonomous vehicle will not be considered as a new product put into circulation. Yet, even in that hypothesis, problems can arise. Ten years after the original product was put into circulation - the self-driving vehicle in 2018 - a liability vacuum is at risk of occurring. As opposed to many products such as bottles, cell phones or laptops, autonomous vehicles will probably be used longer than ten years. Deciding otherwise would mean a throwback compared to today's average car age, which is approximately twelve to fifteen years.

\section{Concluding Remarks - The European Union and Technological Evolutions}

Legal issues related to self-driving cars are thus increasingly addressed at different levels and in several studies or working groups. This of course is a good thing as it allows legislators to catch-up with technological evolutions. However, such legal initiatives, although more than necessary, might not be effective without a proper framework dealing with the liability for damage caused by autonomous vehicles. Both types of legislation - technical issues vs. liability - are needed to address adequately the challenges posed by the autonomisation and robotisation of our society. In that regard, we see an important role for supranational institutions and policymakers. The European Union is best placed to develop a proper framework addressing the transnational threats and risks associated with technological evolutions (cf. the principle of subsidiarity). By taking that role, the EU could protect its citizens against potential disadvantages and uncertainties associated with these evolutions. Could this not be a minor but feasible step to bridge the existing gap between the European Union and its citizens?

\section{Author Information}

Jan De Bruyne obtained a Master degree in Law from the Ghent University in 2012 and Master degree in EU Studies in 2008 at the same university. He is Academic Assistant in the field of

\footnotetext{
${ }^{21}$ The reference to the endangerment of the health and safety of persons and animals, as well as the protection of properties, is a reoccurring element used by the European Union legislator in the context of the free movement of goods. See e.g. Directive 2014/35/EU of the European Parliament and of the Council of 26 February 2014 on the harmonisation of the laws of the Member States relating to the making available on the market of electrical equipment designed for use within certain voltage limits [2014] OJ L/96.
} 
comparative and private law at the Department of Interdisciplinary Study of Law, Private Law and Business Law of the University of Ghent. He has been a Visiting Fellow at the Institute of European and Comparative Law of Oxford University and at the Center for European Legal Studies of the University of Cambridge. He has written many articles in international peer-reviewed journals on the liability for damage caused by autonomous vehicles, third-party certifiers and punitive damages. He is member of the board of the International Transport Law Review and spoke at different conferences on commercial law topics.

Jarich Werbrouck obtained his Master in Law from the Ghent University in 2017. He did extensive research on the application of the Product Liability Directive in the context of autonomous vehicles. His article is currently under peer review for publication in the Tijdschrift voor Privaatrecht. As from February 2018, he will conduct research in the field of consumer and civil procedural law at the Department of Interdisciplinary Study of Law, Private Law and Business Law of the University of Ghent in the context of a project funded by the Research Foundation - Flanders. 